\title{
ECONOMIC ANALYSIS OF THERMAL DESALINATION PLANTS USING DEAS PROGRAM
}

\author{
Salah Al-Hengari ${ }^{1}$, Mohamed El-Bousiffi², Walid El-Moudir ${ }^{3}$ \\ ${ }^{1}$ Libyan Academy, School of Applied Science and Engineering, Chemical and Petroleum \\ Engineering Department, Tripoli - Libya \\ ${ }^{2}$ Libyan Petroleum Institute, Tripoli - Libya \\ ${ }^{3}$ HTC Purenergy Ing., 0012305 Victoria Avenue, Regina, SK, S4P 0S7, Canada. \\ *salah.alhengari@academy.edu.ly
}

\begin{abstract}
This paper provides an overview of the potential use of Desalination Economic Analysis Spreadsheets DEAS package; implemented as Excel spreadsheets in economic evaluation and analysis of thermal desalination plants; especially multi stage flashing (MSF) and multi effect evaporation with / without thermal vapor compression (MEE / MEE-TVC). The DEAS package program has been developed by the researchers. DEAS has been developed and used during the evaluation of thermal desalination plants in the oil sector in Libya. Cost data obtained from various sources were used to evaluate the economic performance and the cost of producing one $\mathrm{m}^{3}$ of distillate water. Different aspects of economic evaluation were discussed in which the attractive potential utilization of DEAS program is shown. The results obtained from DEAS program showed that the increase of plant capacity (although it increased the capital cost) reduced the product unit cost. In addition, an estimate of the unit product cost of thermal desalination processes could be done quickly and accurately through DEAS.
\end{abstract}

Keywords: Economic Evaluation; Thermal Desalination Plants; DEAS package program; unit production cost.

\section{Introduction}

The availability of process water for chemical or petrochemical industries is essentially important. Lack of natural sources of such water with restricted specifications in Libya is a major barrier that face industrial projects. The possible option to secure sufficient quantities of this process water in the long term is through the desalination of seawater. Desalination plants, which may use wasted thermal sources such as low-grade steam, were put into operation at a number of Libyan oil industrial sites.

In Libya and since 1960s thermal desalination processes have been the most applied water desalination processes for industrial purpose. Non thermal processes such as Reveres Osmosis (RO) or Elector Dialysis (ED) were rarely used; nevertheless, these technologies have been widely used when water demand is small such as in hospitals, hotels, food facilities and other domestic applications, (see Figure (1a) and Figure (1b)). 


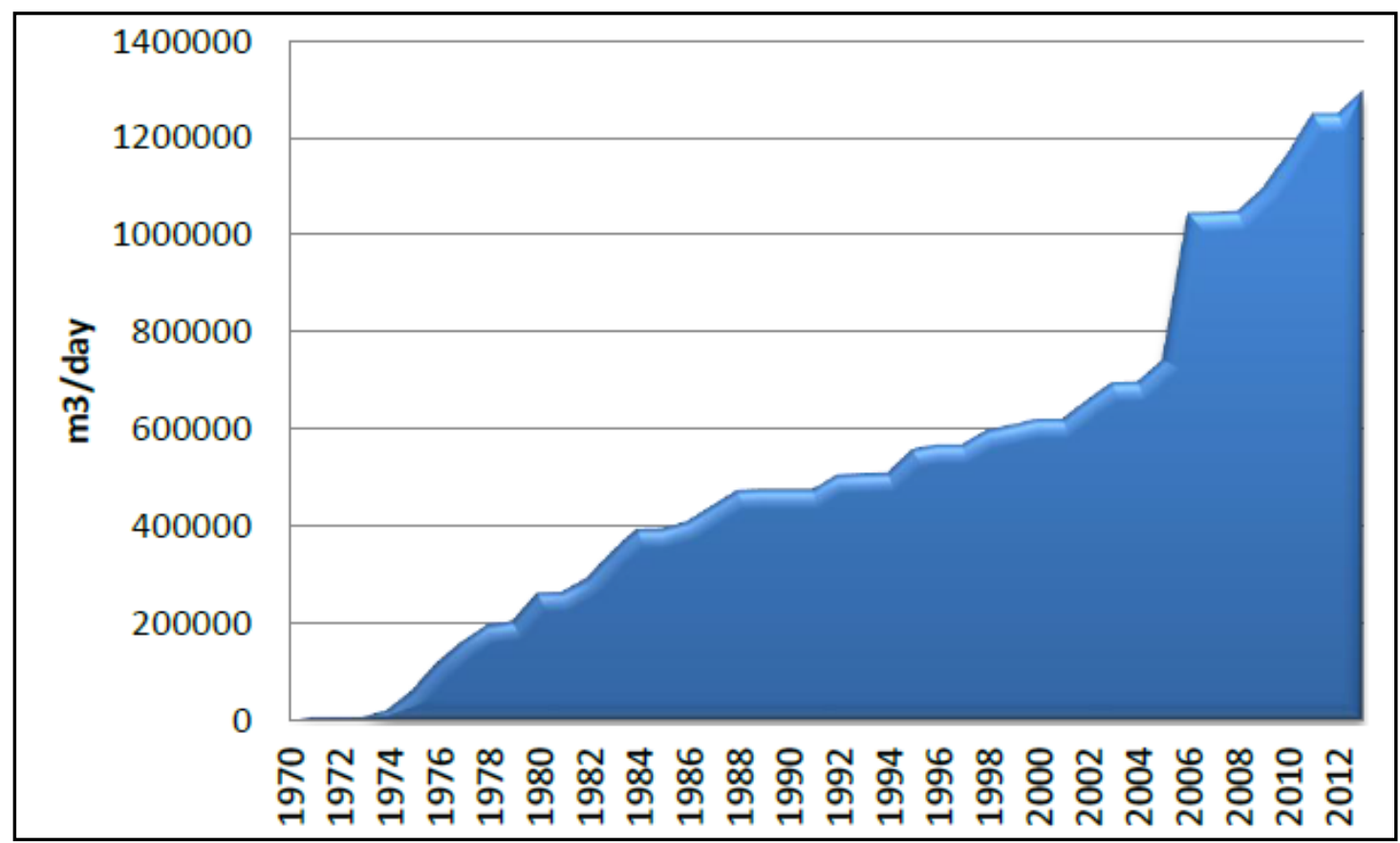

Figure (1a): Cumulative installed desalination capacity in Libya from 1975 to 2013 in m³/day (UNEP, June 2015).

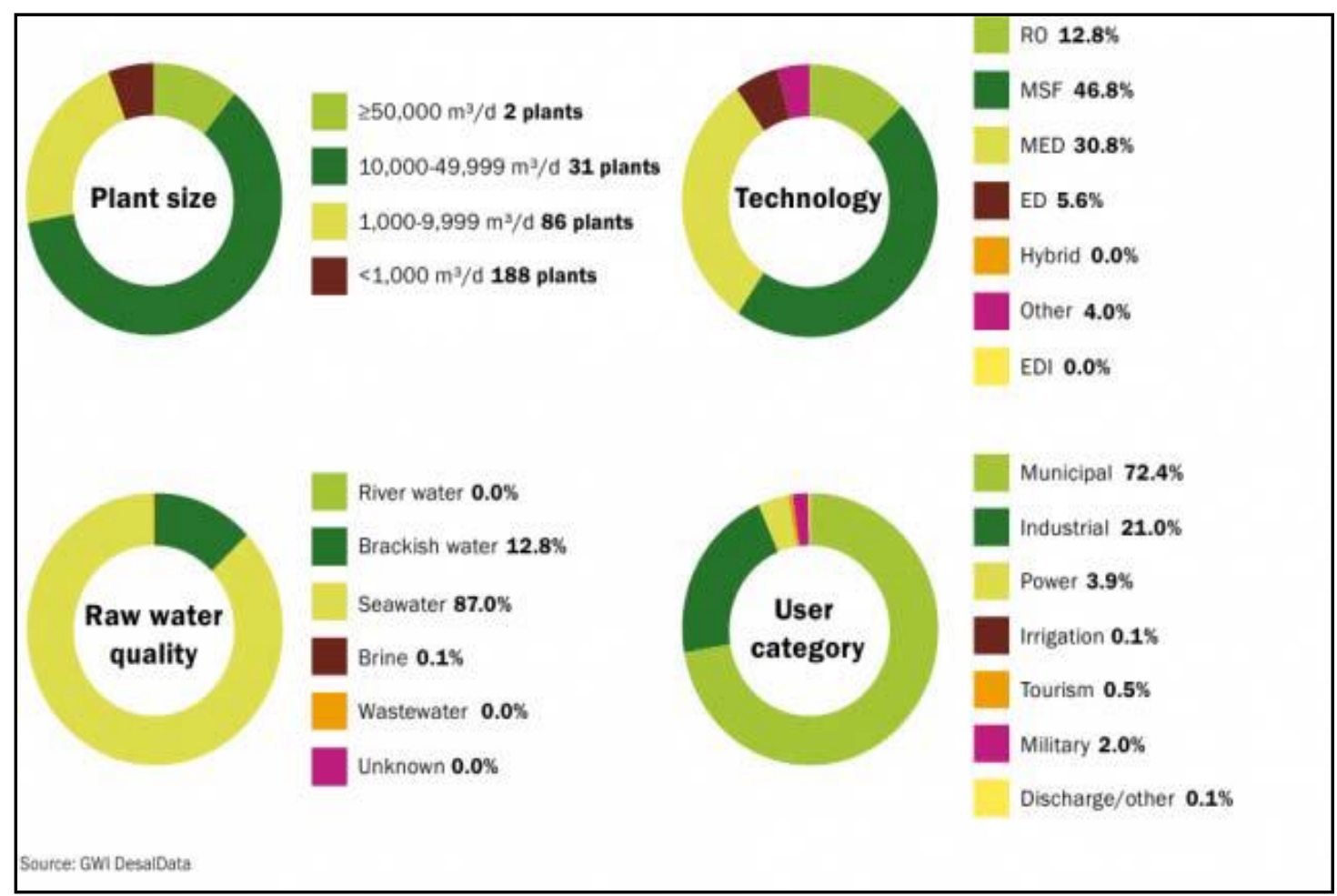

Figure (1b): Libya installed capacity by plant size, technology, raw water quality and user category (UNEP, June 2015). 
The thermal processes offer a huge amount of distillate water with high purity (Salinity $\leq$ $10 \mathrm{ppm}$ ) and at reasonable costs. Distillate water produced at thermal units (e.g. MSF) can be used directly and without further additional treatment in an industrial unit such as boiler, see Figure (2).

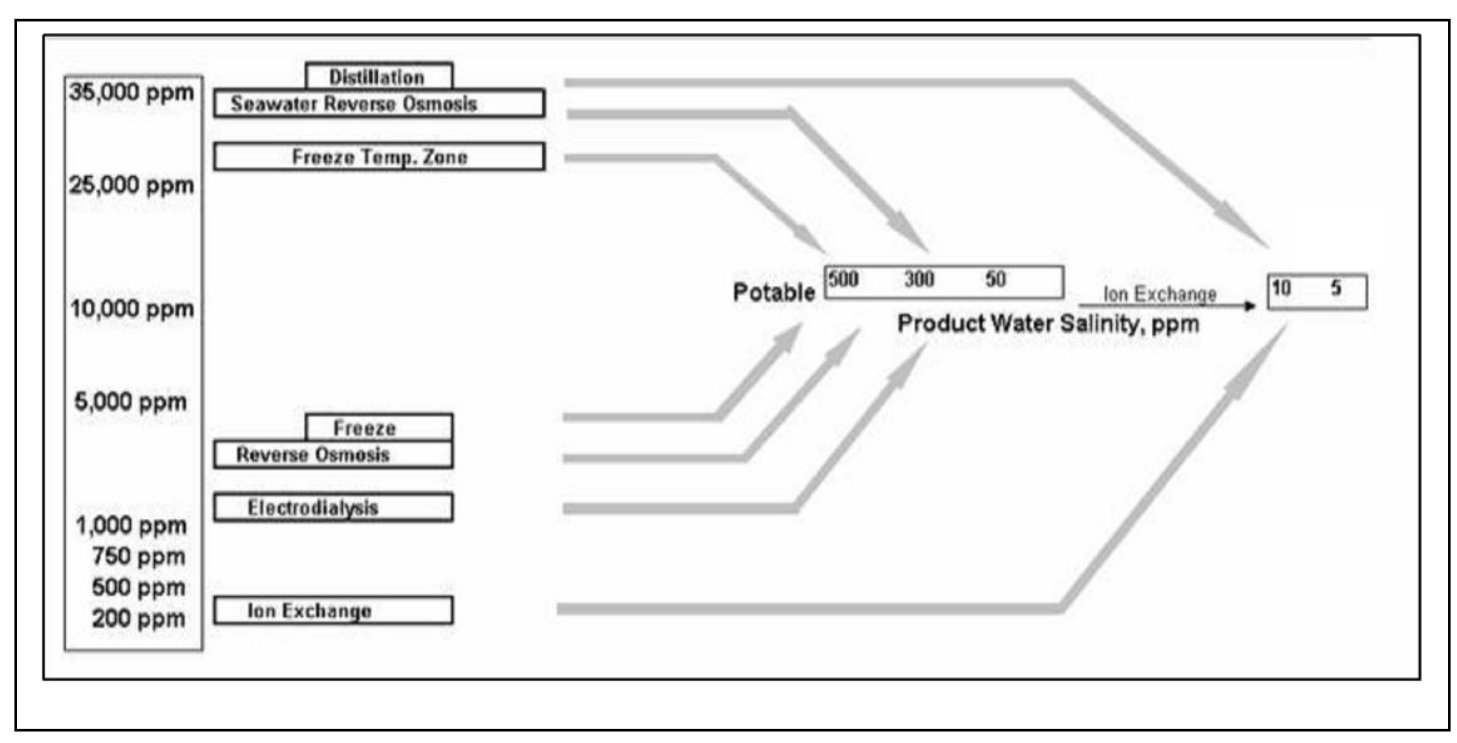

Figure (2): Feed Salinity and Product Purity vs. Desalination Technologies.

There are several alternatives thermal technologies available such as MSF and MED-TVC (Figure (3)). These technologies are adopted in Libya and the first desalination unit (MSF) was installed in 1964 in one of the oil processing site.

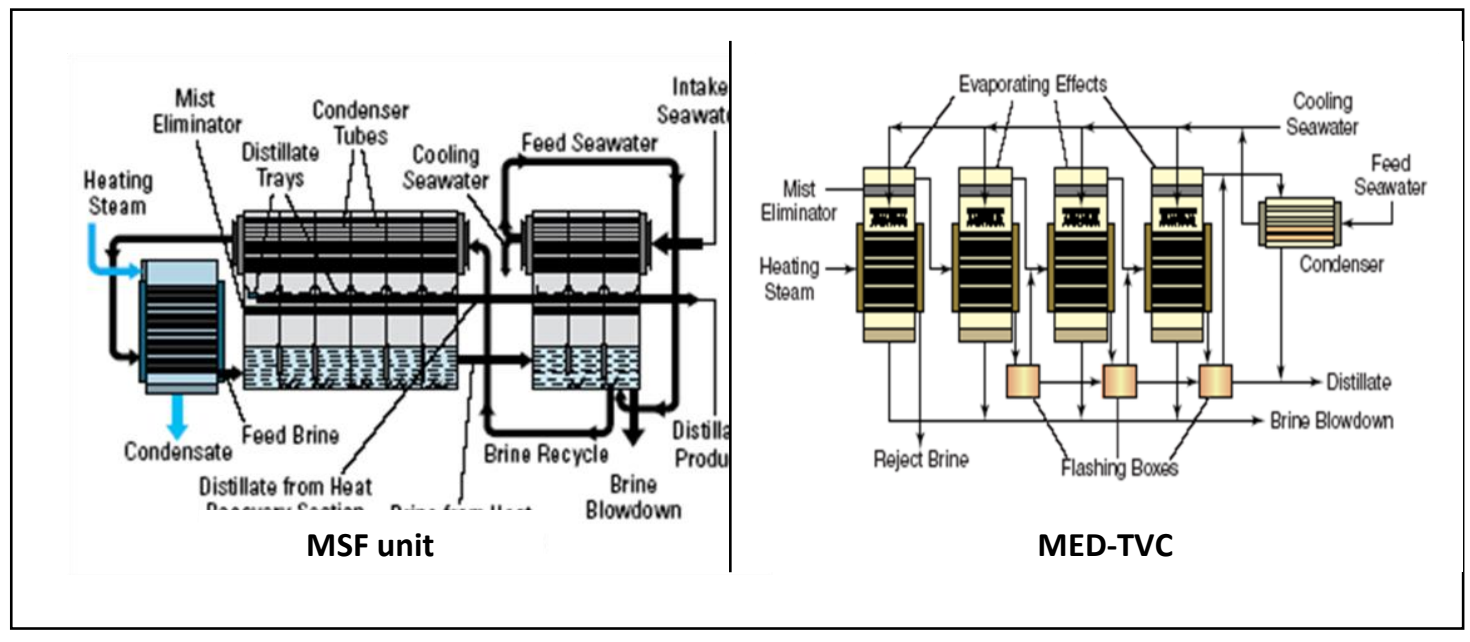

Figure (3): Flow Diagrams of MSF and MED-TVC Processes (H. M. Ettouny et. al., Dec. 2002). 
Temperature has a great effect on the performance desalination process in thermal units. MED plants operate at lower temperatures $\left(63^{\circ}-75^{\circ} \mathrm{C}\right)$ than $\mathrm{MSF}$ plants $\left(100^{\circ}-110^{\circ} \mathrm{C}\right)$, which reduces operational problems that result from scaling and corrosion. MED pumping and electrical power requirements are typically 33\% lower than MSF, and seawater intake water requirements may be $50 \%$ lower than a similarly sized MSF. All these factors should be examined when a suitable technology is selected for new units. One of the important factors of thermal desalination unit is the Performance Ratio (PR) which is the ratio of $\mathrm{kg}$ of water produced to one $\mathrm{kg}$ of steam consumed. For example, in a typical MED unit, each kilogram of input steam can be used to produce eight kilograms of product water.

\section{Desalination Economics}

This section is to present the elements of desalination economics evaluation in order to estimate the cost $\$ / \mathrm{m}^{3}$ of water. A convenient method for estimating the cost of desalted water is illustrated. Moreover, the analysis explains why the estimation of accurate water cost is quite difficult task.

The economic analysis is concerned with desalination plants that are used to produce water only e.g. not dual purpose plants to generate electricity and produce water. The components of fixed cost and operating cost are outlined.

The calculation of the unit product cost depends on the process capacity, site characteristics, and design features. System capacity specifies sizes for various process equipment and pumping units.

\section{Unit Product Cost $=$ Fixed Costs + Operating Costs}

Factors that determine the cost of water production include both fixed and operating charges. The components of these costs are listed in below (Figure (4)). Costs are usually calculated on annual or monthly basis.

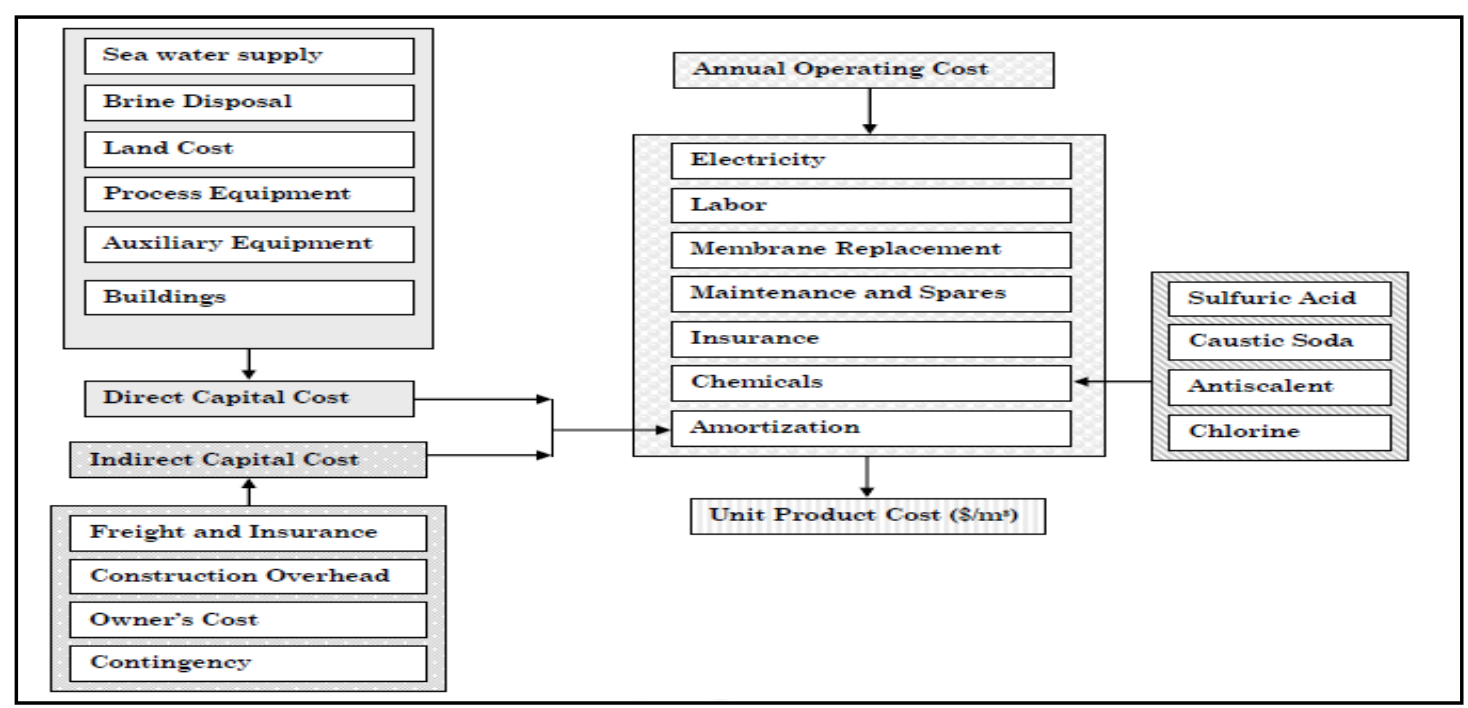

Figure (4): Unit Product Cost Items and Factors (H. M. Ettouny et. al., Dec. 2002). 


\section{Fixed Costs}

Fixed charges that must be included in the total cost of producing water from a desalination process are predominantly the result of capital costs. They mainly consist of amortization and interest to recover the installed cost of the plant, i.e. the capital cost of the

$$
f_{r}=r+\frac{r}{(1+r)^{N}-1}=\frac{r \times(1+r)^{N}}{(1+r)^{N}-1}
$$

plant is a fixed cost to be paid annually for repayment of the loan required for financing the project. The amount of these payments will depend on the total cost of the installation, the applicable interest rate and amortization period. The capital Recovery factor $\left(f_{r}\right)$ is given as

Where ' $r$ ' is the interest rate, ' $\left(r /(1+r)^{N}-1\right)$ 'is the sinking fund depreciation factor, and ' $N$ ' is the amortization period which equal to number of annual payments.

The capital recovery factor ' $f_{r}$ ' is calculated for a selected value of $r$ and $N$ as given in Table (1).

\section{Table (1): Capital Recovery Factor $\left(f_{\mathrm{r}}\right)$}

\begin{tabular}{|l|c|c|c|}
\hline & \multicolumn{3}{|c|}{ Interest Rate, $\mathbf{r}$ \% per year. } \\
\hline $\mathbf{N}$ (year) & 5 & 7.5 & 10 \\
\hline $\mathbf{1 0}$ & 0.128 & 0.146 & 0.163 \\
\hline $\mathbf{2 0}$ & 0.08 & 0.100 & 0.117 \\
\hline
\end{tabular}

The sinking fund depreciation takes into account the timing of returned money by including the interest rate. If the installed cost for the plant is $\$ \mathrm{I}$, then the annual capital cost would be $\mathrm{I} \times f_{\mathrm{r}}(\$ / \mathrm{yr})$. The other fixed costs are due to charges for property taxes and insurance. These are usually about $1 / 2 \%$ of the installed cost of the plant.

- The plant availability factor (AF) influences water cost in rigorous estimate. Forced and planned outage of a desalination unit for maintenance and repair reduces its availability for production. Whether the plant is operating or out of operation, fixed charges are paid. Design considerations such as selection of materials of construction, degree of sparing of pumps and control valves, reliability of off-site facilities, and selection of superior equipment components influence the availability of the plant. Table 2 illustrates an example of the influence of AF and Capacity Factor (CF) on the annual fixed cost. The plant has a capacity of $454.6 \mathrm{~m}^{3} /$ day and the plant total annual fixed cost (AFC) equals to $\$ 67,500 / \mathrm{yr}(\mathrm{AFC}=$ Interest \& Amortization + Tax \& Insurance):

\section{Specific annual fixed cost $=$ AFC / (plant capacity X AF X CF)}


Table (2): Illustration of Influence of Availability and Capacity Factors

\begin{tabular}{|l|c|c|c|}
\hline & Case 1 & Case 2 / Case 3 & Case 4 \\
\hline Capacity factor & 1 & $1 / 0.9$ & 0.9 \\
\hline Availability factor & 1 & $0.9 / 1$ & 0.9 \\
\hline Specific Annual Fixed Cost & $\$ 0.406 / \mathrm{m}^{3}$ & $\$ 0.452 / \mathrm{m}^{3}$ & $\$ 0.502 / \mathrm{m}^{3}$ \\
\hline
\end{tabular}

For more comparison, plant factor is a combined factor of availability and capacity factor $(\mathrm{PF}=\mathrm{AF} \mathrm{X} \mathrm{CF})$. This factor has a great effect on the specific annul fixed cost (Figure (5)).

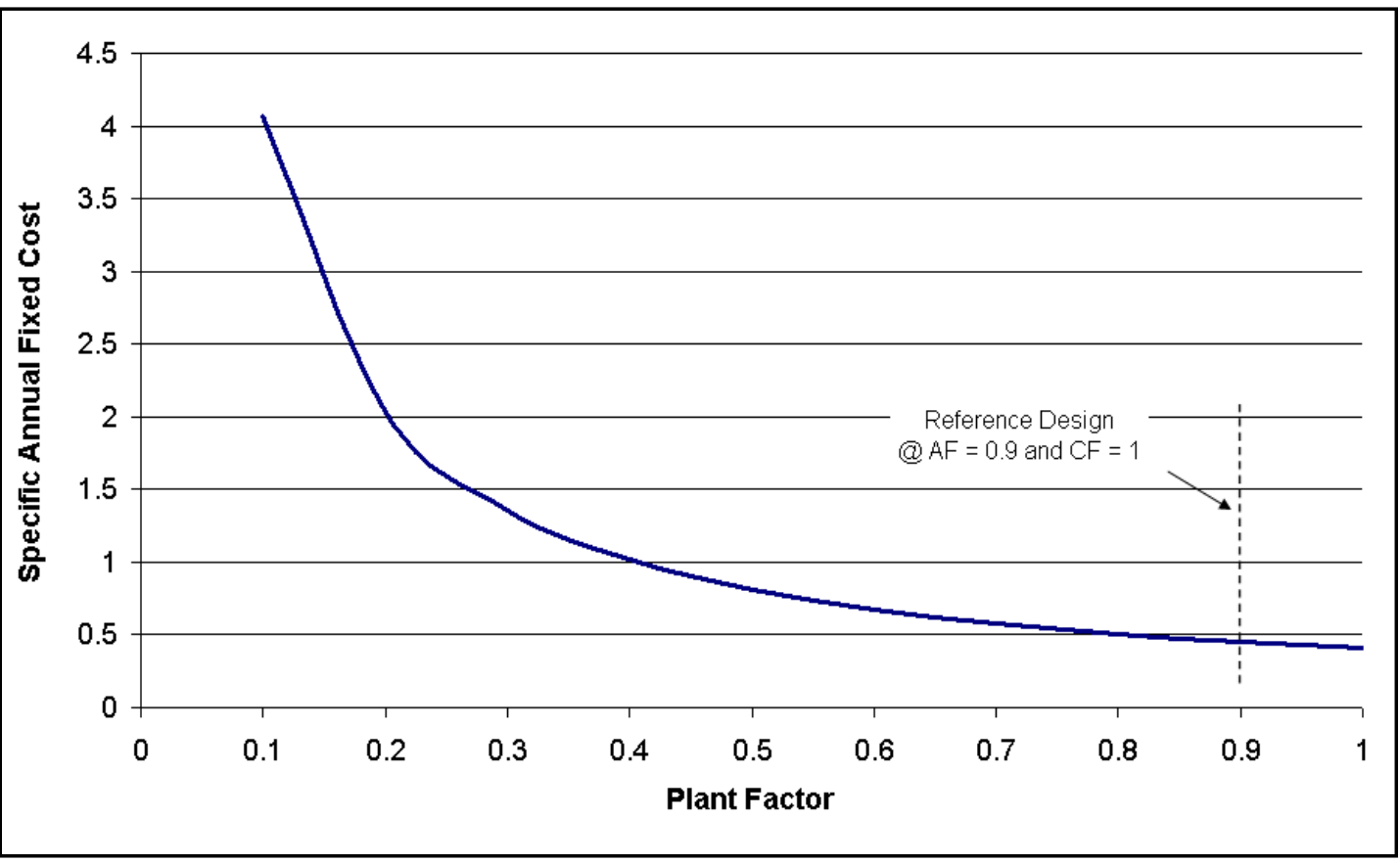

Figure (5): Specific Annual Fixed Cost vs. Plant Factor.

- The capital investment cost of installed plant consists of delivered cost plus cost of erection. A location factor has to be considered through multiplying the installed cost of a plant by a location factor $>1.0$ which depends on the plant location (a location factor of space 1.0 is set for the eastern USA coast).

- Installed plant cost can be estimated by the Specific Installed Cost (SIC) of thermal desalination units and the plant capacity. SICs for an MED plant is lower than for an MSF plant by $10-20 \%$. 
Table (3): Specific Installed Cost (SIC) of Desalination Units

\begin{tabular}{|c|c|c|c|c|c|}
\hline & Year & MSF & $\begin{array}{c}\text { MED or } \\
\text { MED-TVC }\end{array}$ & $\begin{array}{l}\text { MED- } \\
\text { MVC }\end{array}$ & RO \\
\hline $\begin{array}{l}\text { SIC, } \$ /\left(\mathbf{m}^{3} / \text { day) (De- }\right. \\
\text { salinating water - } \\
\text { Google Answers, 2019) }\end{array}$ & Typical & 1481 & & & 500 \\
\hline $\begin{array}{l}\text { SIC, } \$ /\left(\mathbf{m}^{3} / \text { day) (H. M. }\right. \\
\text { Ettouny et. al., Dec. } \\
2002)\end{array}$ & 1996-97 & & $900-1600$ & & 1000 \\
\hline $\begin{array}{l}\text { SIC, } \$ /\left(\mathbf{m}^{3} / \text { day) (H. M. }\right. \\
\text { Ettouny et. al., Dec. } \\
2002)\end{array}$ & $1992-93$ & $1500-2269$ & $1562-2100$ & & 1665 \\
\hline $\begin{array}{l}\text { SIC, } \mathbf{\$} /\left(\mathbf{m}^{\mathbf{3}} / \mathbf{d a y}\right) \\
\text { (International Atomic } \\
\text { Energy Agency, 1997) }\end{array}$ & $\begin{array}{l}\text { Med. } \\
1990 \mathrm{~s}\end{array}$ & & $900-1600$ & & $800-1200$ \\
\hline $\begin{array}{l}\text { SIC, } \$ /\left(\mathbf{m}^{\mathbf{3}} / \text { day }\right)(\text { The } \\
\text { World's Water, 2003) }\end{array}$ & $\begin{array}{l}\text { Early } \\
2000\end{array}$ & $1,100-1,600$ & $900-1,250$ & & $\begin{array}{l}700- \\
1,000\end{array}$ \\
\hline $\begin{array}{l}\text { SIC, } \$\left(\mathbf{m}^{3} / \text { day) }\right. \\
\text { (Encyclopaedia of } \\
\text { Desalination and Water } \\
\text { Resources, 2019) }\end{array}$ & $?$ & 1,000 & 2,000 & $2,500-3000$ & $\begin{array}{l}800- \\
1,250\end{array}$ \\
\hline $\begin{array}{l}\text { SIC, } \$ /\left(\mathbf{m}^{3} / \text { day) }(\text { The }\right. \\
\text { World's Water, (2003) }\end{array}$ & $\begin{array}{c}\text { Recent } \\
\text { estimation }\end{array}$ & $1,050-3,150$ & & & \\
\hline $\begin{array}{l}\text { SIC, } \$ /\left(\mathbf{m}^{3} / \text { day) }\right. \\
\text { (International Atomic } \\
\text { Energy Agency, Dec. } \\
2000)\end{array}$ & $1990 \mathrm{~s}$ & 1800 & 900 & & 800 \\
\hline $\begin{array}{l}\text { SIC, } \$ /\left(\mathbf{m}^{3} / \text { day) }(\mathrm{E} .\right. \\
\text { Wheida, R. Verhoeven, } \\
2004)\end{array}$ & 2003 & & $1450-1700$ & & \\
\hline $\begin{array}{l}\text { SIC, } \$ /\left(\mathbf{m}^{3} / \text { day }\right)(\mathrm{E} . \\
\text { Wheida, R. Verhoeven, } \\
\text { 2004) }\end{array}$ & $?$ & 2000 & 1500 & & 1300 \\
\hline $\begin{array}{l}\text { SIC, } \$ /\left(\mathbf{m}^{3} / \text { day) (S Al- }\right. \\
\text { Hengari, W. ElMoudir, } \\
\text { M. El-Bousiffi, 2015) }\end{array}$ & $1980 \mathrm{~s}$ & Average 1500 & Average 1300 & - & - \\
\hline $\begin{array}{l}\text { SIC, \$/(m³/day) (S Al- } \\
\text { Hengari, W. ElMoudir, } \\
\text { M. El-Bousiffi, 2015) }\end{array}$ & $1990 \mathrm{~s}$ & Average 1700 & Average 1600 & - & - \\
\hline
\end{tabular}

\section{Operating Costs}

\section{Fuel Costs (Steam Costs)}

Fuel costs makes up the greatest part of the total production cost of water. The cost of fuel for product water varies directly with the price of fuel and inversely with performance 
ratio, PR; low PR means high steam consumption and hence high fuel consumption. Although, the international prices for fuel are subject to change at any time, fuel prices are quite constant on yearly basis in Libya, e.g. fuel oil $\approx \$ 28 /$ ton (S. Al-Hengari, W. ElMoudir, M. El-Bousiffi, 2015). As far as the exhausted thermal sources of energy can be used as saturation steam, this source energy will save substantial part of costs. The steam cost can vary from $\$ 2-3.5 /$ ton (N. M. Wade, 2001) and as far as the steam loses its kinetic energy and keeps its heat energy, the steam becomes much cheaper (superheated steam cost $>\$ 3 /$ ton < saturation steam cost). The recovered steam from waste streams will be a free source of energy.

\section{Power Cost}

Power consumption depends on the size of the plant and mode of distillation. MED plants consume less power than MSF plants, which require higher power consumption for recycle pumps, however, MED plants do not. On the other hand, MED-TVC units consume much less power than MED-MVC units do; the later are power intensive process. In fact, power may cost less especially on-site generation. For estimation purpose, power cost can be taken as $\$ 0.04-0.09 / \mathrm{kWh}$ (H. M. Ettouny et. al., Dec. 2002) and average value can be taken $\$ 0.037 / \mathrm{kWh}$ (S. Al-Hengari, W. ElMoudir, M. El-Bousiffi, 2015) in Libya. Estimated energy requirements of three type desalination plants are shown in Table (4).

Table (4): Energy requirements comparison between MSF and RO

\begin{tabular}{|l|c|c|c|c|}
\hline & MSF $^{+}$ & MED $^{++}$ & \multicolumn{2}{|c|}{ RO } \\
\hline Possible Desalination Unit Size & $\approx 60,000$ & $*$ & $\approx 24,000^{+++}$ & $*++$ \\
\hline Energy Consumption, $\mathbf{k W h} / \mathbf{m}^{\mathbf{3}}$ & $4-6$ & $1-2.5$ & $5-7$ & $4-7$ \\
\hline Electrical equivalent for thermal energy $\mathbf{, k W h} / \mathbf{m}^{\mathbf{3}}$ & $8-18$ & $4-7$ & - & - \\
\hline Total Equivalent Energy Consumption, $\left.\mathbf{( k W h} / \mathbf{m}^{\mathbf{3}}\right)$ & $12-24$ & $5-9.5$ & $5-7$ & $4-7$ \\
\hline
\end{tabular}

${ }^{+}$Encyclopaedia of Desalination and Water Resources, 2019.

${ }^{++}$International Atomic Energy Agency,1997.

+++ Encyclopaedia of Desalination and Water Resources, 2019.

* Unmentioned.

\section{Labour Costs}

The payroll of the plant will include mainly permanent staff for operation, routine maintenance and administration. Labour costs include desalination plant's operators and management staff. The figure can be varied from place to another and for local or overseas labor.

\section{Chemical Treatment Costs}

All desalination plants are usually designed to operate on an antiscale program to prevent scale formation along with periodic acid cleaning. Multi Effect Distillate (MED) units 
consume less of chemicals since they use less feed seawater compared with MSF plants. Table (5) shows the typical costs of a number of chemicals used in desalination unit.

Table (5): Estimation of Chemical Cost and Dosing Rates (H. M. Ettouny et. al., Dec. 2002)

\begin{tabular}{|c|c|c|c|}
\hline Chemical & $\begin{array}{c}\text { Unit Cost } \\
(\$ / \mathrm{kg} \text { of chemicals })\end{array}$ & $\begin{array}{c}\text { Typical Dosing Rate } \\
\text { (kg chemical/ Kg water) }\end{array}$ & $\begin{array}{l}\text { Specific Cost } \\
\left(\$ / \mathrm{m}^{3} \text { water }\right)\end{array}$ \\
\hline Sulfuric Acid & 0.504 & $2.42 \mathrm{E}-5$ & 0.0122 \\
\hline Antiscalent & 0.701 & $1.4 \mathrm{E}-5$ & 0.0098 \\
\hline
\end{tabular}

\section{Maintenance Costs}

They include spare parts and manpower for non-routine maintenance. These costs are usually estimated on the basis of the labour experience, plant size and age, and location. Generally speaking, this can be considered as a fixed cost amounting yearly to $1-1.5 \%$ of the total installed cost of the medium plant size, see table (6).

Table (6): Typical Maintenance Cost Factor for Thermal Units (R. Bakish, Practice of Desalination, 1973)

\begin{tabular}{|c|c|c|c|}
\hline $\begin{array}{c}\text { Production } \\
\text { Capacity }\end{array}$ & $\begin{array}{c}\text { Installed Plant Cost } \\
\text { (IEC) }\end{array}$ & $\begin{array}{c}\text { Maintenance cost } \\
\text { factor, \% of IEC }\end{array}$ & $\begin{array}{c}\text { Annual } \\
\text { Maintenance Cost }\end{array}$ \\
\hline $454.6 \mathrm{~m}^{3} /$ day & $\$ 200,000$ & 4 & $\$ 8,000$ \\
\hline $4546 \mathrm{~m}^{3} /$ day & $\$ 750,000$ & 1.5 & $\$ 11,250$ \\
\hline
\end{tabular}

\section{Overhead Costs}

These figures are used in order to fulfil any money flow shortage for a project. If this item is not available for calculations it can be taken as $100 \%$ of labour cost (A. Lamei, Pieter van der Zaag, Elisabeth Von Muench, May 2008).

\section{Factors Affecting the Product Cost}

\section{Salinity and Quality of Feed Water:}

- Lower feed salinity allows for higher conversion rates.

- Dosing rate of antiscalent chemicals are less when the feed has low salinity.

- Downtime related to scaling is considerably reduced at lower salinity.

Plant Capacity: Larger plant capacity reduces the capital cost for a unit product although, the increase in the plant capacity implies higher overall capital. 
Site Conditions: Installation of new units as an addition to existing sites, would eliminate cost associated with facilities for feed water intake, brine disposal, and feed water pretreatment.

Qualified Manpower: Availability of qualified operators, engineers, and management would result in higher plant availability, production capacity, and lower down time which is usually caused by faulty devices trips.

Energy Cost: Availability of inexpensive sources of fuel, electric power and heating steam have a strong impact on unit product cost.

Plant Life and Amortization: Increase in plant life reduces the product cost.

\section{Unit Product Cost}

In general, production costs tend to be in the range of $\$ 1-4 / \mathrm{m}^{3}$ (The World's Water, 2003), (H. M. Ettouny et. al., Dec. 2002) depends on the technology applied, the size of the unit, capital cost, operating costs and other factors. Lower figures can be achieved through using cheaper sources of energy. The typical ranges of unit product cost of seawater desalination are:

i. Large plants

\$ 0.75 - \$ 1.5/m³ (Ettouny et. al., 2002; El-Dessouky et. al., 2002; De-salinating water - Google Answers, 2019).

ii. Small plants $\$ 2.00$ - \$ 3.0/ $\mathrm{m}^{3}$ (Ettouny et. al., 2002; El-Dessouky et. al., 2002; De-salinating water - Google Answers, 2019).

Table (7): Comparison of Water Produced by RO and MSF Units (A. Lamei, Pieter van der Zaag, , Elisabeth Von Muench, May 2008)

\begin{tabular}{|c|c|c|c|c|}
\hline \multirow{2}{*}{ Technology } & $\begin{array}{c}\text { Production } \\
\text { Capacity, } \mathbf{~ m}^{\mathbf{3}} \mathbf{/ d a y}\end{array}$ & $\begin{array}{c}\text { Fixed } \\
\mathbf{C h a r g e s} \\
\mathbf{\$} / \mathbf{m}^{\mathbf{3}}\end{array}$ & $\begin{array}{c}\text { Operating } \\
\text { Charges, } \mathbf{\$} / \mathbf{m}^{\mathbf{3}}\end{array}$ & $\begin{array}{c}\text { Water Cost } \\
\mathbf{\$} / \mathbf{m}^{\mathbf{3}}\end{array}$ \\
\hline \multirow{3}{*}{ RO } & $1,454.75$ & 1 & 0.75 & 1.75 \\
\cline { 2 - 5 } & $4,546.1$ & 0.75 & 0.7 & 1.45 \\
\cline { 2 - 5 } & $22,730.4$ & 0.5 & 0.7 & 1.2 \\
\hline \multirow{3}{*}{ MSF } & $1,454.75$ & 1.5 & 1.05 & 2.55 \\
\cline { 2 - 5 } & $4,546.1$ & 1 & 1 & 2 \\
\cline { 2 - 5 } & $22,730.4$ & 0.5 & 0.85 & 1.35 \\
\hline
\end{tabular}

The definition of large or small plants depends on the mode of desalination process used and production capacity. Distillation mode desalination plants such as MSF plants are usually considered large size plants $\left(2,000-20,000 \mathrm{~m}^{3} /\right.$ day $)$, whereas MED or MED-TVC plants are viewed as medium/small size units $\left(\leq 5,000 \mathrm{~m}^{3} / \mathrm{d}\right)$. The economic benefit of large scale plants is clearly evident from Table 7. In Libya, the estimation of the cost of one 
cubic meter of desalted water is around $\$ 1-3 / \mathrm{m}^{3}$ (S. Al-Hengari, M. El-Bousiffi, W. ElMoudir, 2007; S Al-Hengari, W. ElMoudir, M. El-Bousiffi, 2015; E. Wheida, R. Verhoeven, 2004).

\section{Desalination Economic Analysis Spreadsheet, DEAS}

Excel spreadsheets have been developed by the Authors under the name of "Desalination Economic Analysis Spreadsheets, DEAS". A well-known economic methodology to conduct the economic analysis have been used.

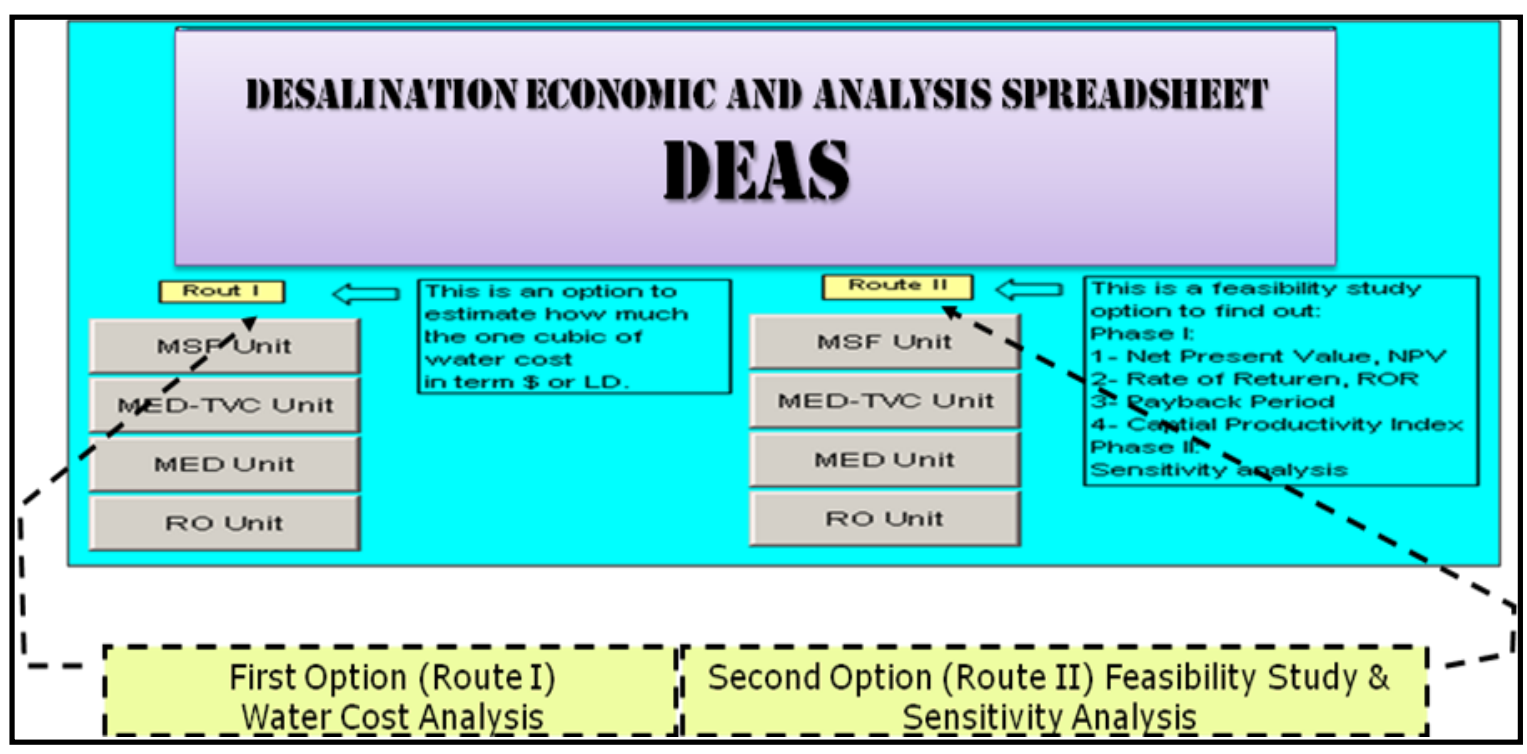

Figure (6): Desalination Economic Analysis Spreadsheets

However, this package is still under development to acquire more information and to conduct further calculations.

$D E A S$ can be used by plant engineers and operates in order to save time and obtain accurate results. It has two routes calculations capabilities (Fig. 6). The first route (option) can be used for estimating unit product cost of desalted water. The second route (option) can be used to view the feasibility (feasibility study) of installing a new plant or review an existing desalination unit. The basis of evaluation is that the plant should have only one purpose which is producing water (not dual purpose; water and electricity). The second route is completed with sensitivity analysis.

This paper is concerned with only the first route (Route I) which has two calculation options. The first option is for the new units to be installed or the existing units that still paying theirs fixed charges. Therefore, the units are fixed and the operating costs are accounted for (Figure (7)). 


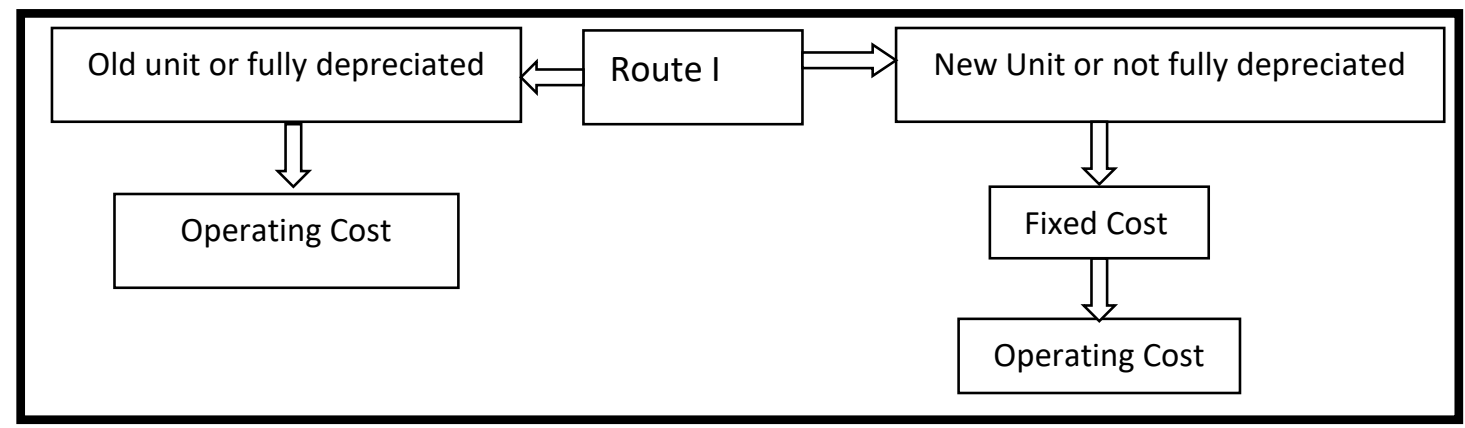

Figure (7): Route I of Water Cost Calculations

The second option is for the units which are old and have already passed their payment time or fully depreciated and still running. Therefore, only the operating costs will be used and this will be selected by the user. The unit product cost calculations are based on the default specific values, major values listed below. These values will be used as a reference unless figures are available:

1. The operation life of each unit can be in the range of $10-30$ years with interest rates ranging from $5-20 \%$ on borrowed capital. These are used for the calculation of capital recovery factor. Therefore, the default figures of lift time and interest rate are 20 years and $10 \%$ receptively.

2. The cost of repair and maintenance including replacement of parts (e.g. pumps, pipes, etc.) the default value is taken as $2 \%$ of installed cost of a plant per year (R. Bakish, Practice of Desalination, 1973).

3. The overhead cost is taken as $100 \%$ of labour cost (A. Lamei, Pieter van der Zaag, , Elisabeth Von Muench, May 2008). This is a fixed cost includes administration, training and indirect costs, etc.

4. The cost of pumping, chemical treatment and filtration of intake seawater will be ignored unless the cost of seawater is entered.

5. The cost of plant cleaning of chemicals is estimated from table (5).

The spreadsheet of Route I consists of three tables and one figure. The first, table (1.1), gives the cost of production at design conditions $(\mathrm{AF}=0.9, \mathrm{CF}=1)$. This table allows the user to see the reference cost figure. The second, table (1.2), gives the cost of production for the selected conditions. The third, table (1.3) shows a comparison between the cost at design and selected conditions. Finally, Figure (1) is a graphical representation of data given in Table (1.3).

For demonstrating $D E A S$, the following case study of an MSF plant which was taken from reference (H. M. Ettouny et. al., Dec. 2002) will be examined. Fig. 9 shows the DEAS input data for the unit and the corresponding results. The example is based on international costs' figures. 


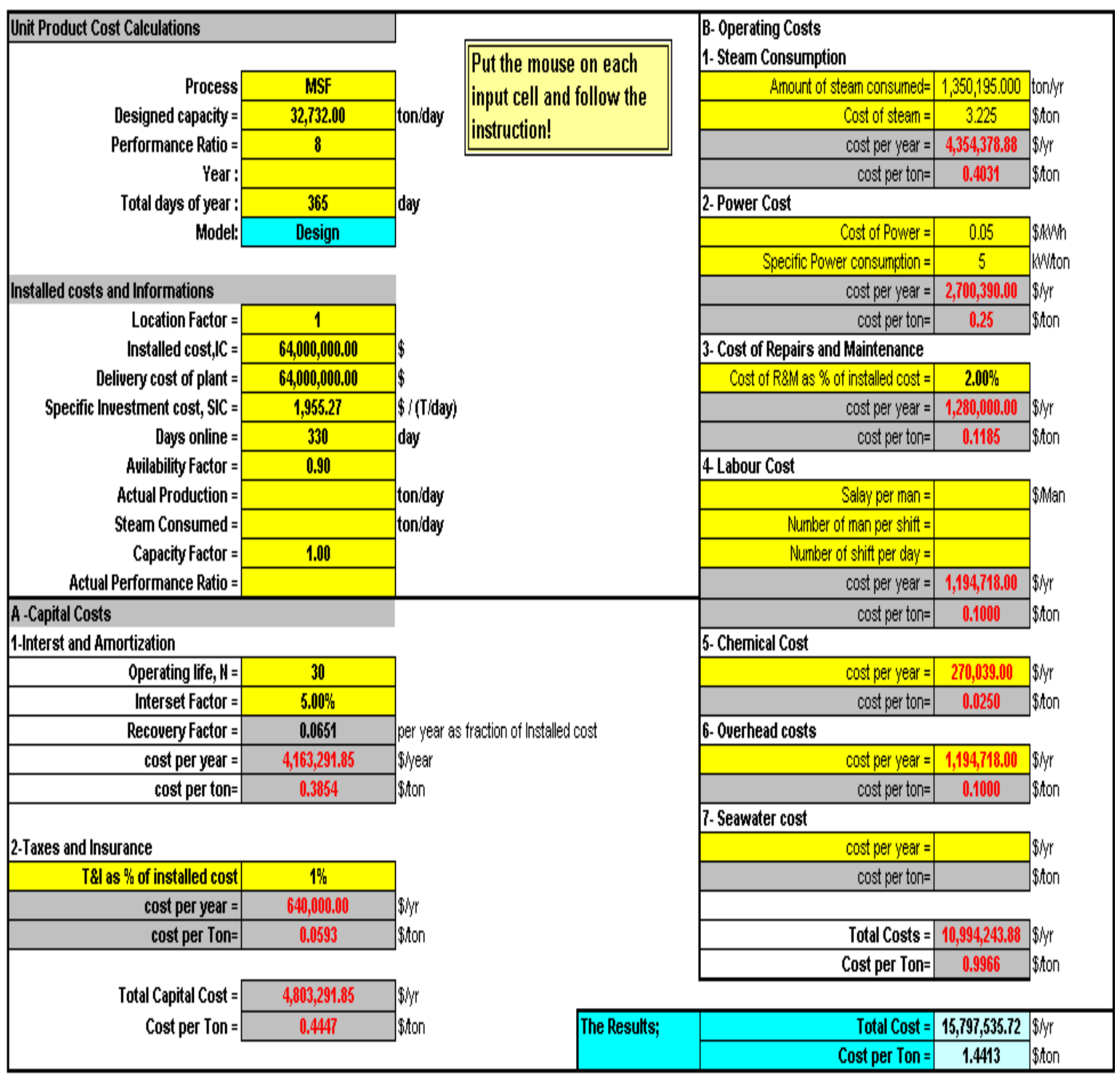

Figure (8): Table (1.1) of Cost Estimation on Design Operation Model*

*Yellow is input data and Gray is output data

As can be seen in Figure (8), the data and information input to the spreadsheet are in the yellow cells. The water cost is $\$ 1.44 / \mathrm{m}^{3}$ based on AF of $90 \%$. 


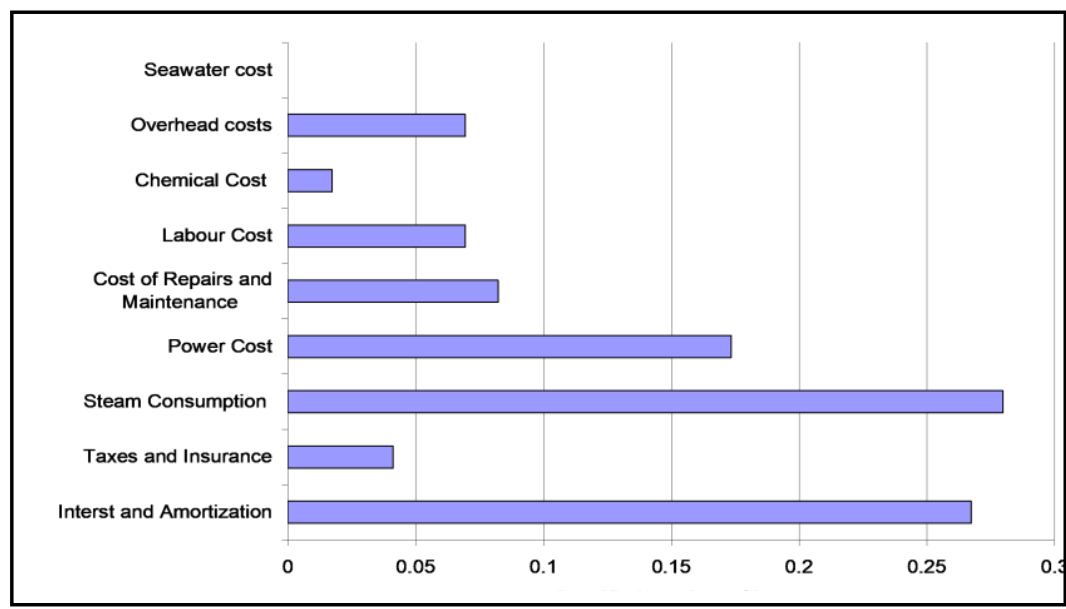

Figure (9): Sharing Comparison of Water Cost of one Cubic Meter

As can be seen in Figure (9), the most shared items of water costs are fixed costs (amortization), steam cost $\$ 0.27 / \mathrm{m}^{3}$ (18.75\% of water cost), and $\$ 0.28 / \mathrm{m}^{3}(19.5 \%)$ respectively. Power consumption is occupying a quite considerable proportion with $11.1 \%$. The total share of the three items is $\$ 0.71 / \mathrm{m}^{3}$ (50\% of water cost).

The availability of the unit has great influence on water cost. As can be seen from Fig. 9 the water cost is $\$ 1.44 / \mathrm{m}^{3}$ at $\mathrm{AF}=90 \%$ and $10 \%$ of the time the unit was out of operation due to planning or forced shutdowns. The effect of AF is a clear evidence in the case of MSF plant. The water cost increases quickly as the AF deteriorates. For example, at AF = 0.75 the water cost is $\$ 1.55 / \mathrm{m}^{3}$ and at $\mathrm{AF}=0.5$ the water cost is $\$ 1.9 / \mathrm{m}^{3}$ (Figure (10)).

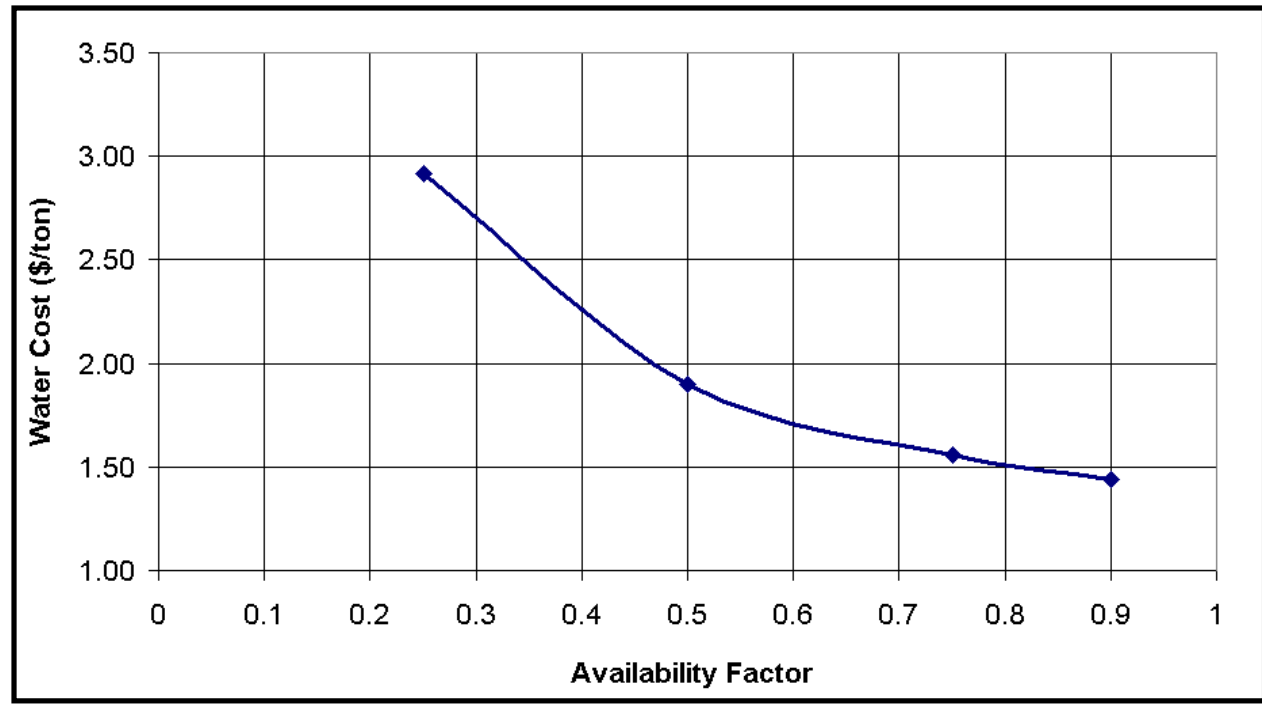

Figure (10): Desalted Water Cost vs. Availability Factor 


\section{Conclusion}

- Although increasing plant capacity increases the capital cost, it has a strong effect on reducing the product unit cost.

- An accurate and quick estimate of the unit product cost of thermal desalination processes can be done through $D E A S$.

- MSF unit example shows a drastic reduction in the water cost when AF increases and this is a fact.

- The fixed charges and the energy cost in the MSF and MED processes represent more than $40 \%$ of the total unit product cost.

- The optimum selection of thermal desalination of high salinity water depends on the required capacity; many references show that the MSF process would be optimum for capacities higher than $25,000 \mathrm{~m}^{3} / \mathrm{d}$. The MED process is for capacities averaging $10,000 \mathrm{~m}^{3} / \mathrm{d}$, and the MVC process is for capacities averaging 3,000 $\mathrm{m}^{3} / \mathrm{d}$.

- RO process represents the optimum choice of desalination of low salinity water.

\section{Reference}

- UNEP, (June 2015), final Report for activity 1.3.2.1, MED POL Focal points meeting 1619 "Assessment of Potential Cumulative Environmental Impacts of Desalination Plants around the Mediterranean Sea".

- H. M. Ettouny et. al., (Dec. 2002), "Evaluating the Economic of Desalination", CEP.

- International Atomic Energy Agency, (1997), "Assessment of the Economic Competitiveness of Nuclear and Fossil Energy Options for Seawater Desalination".

- The World's Water, (2003): The Biennial Report on Freshwater Resources, Available at: http://www.siwin.org/ textbase/swtb0013.pdf. (Accessed: 10/ 10/2019).

- Encyclopaedia of Desalination and Water Resources, (2019), Available at: www.desware.net/desware/desa4.asp. (Accessed: 10/ 10/2019).

- R. Bakish, Practice of Desalination, (1973), Noyes Data Corporation, ISBN: 0-8155-04780 .

- Lamei, Pieter van der Zaag, Elisabeth Von Muench, May 2008, Basic cost equations to estimate unit production costs for RO desalination and long-distance piping to supply water to tourism-dominated and coastal regions of Egypt, Desalination 225(1-3):1-12. 
- Hisham T. El-Dessouky, Mohamed Darwish, (2002), Desalination Technologies Course material, Petroleum Research Centre, Tripoli - Libya.

- De-salinating water - Google Answers, (2019), Available at: www.desware.net/desware/desa9.asp, (Accessed: 30/ 09/2019).

- Hassan Khan, (1986), Desalination Processes and Multistage Flash Distillation Practice, Volume 1", Elsevier, ISBN: 0-444-42563-2.

- Max S. Peters and Klaus D. Temmernaus, (1991), Plant Design and Economics for Chemical Engineers", 4th edition, McGraw-HILL International Edition, ISBN: 0-07100871-3.

- N. M. Wade, (2001), Distillation Plant Development and Cost Update, Desalination 136,

- S. Al-Hengari, M. El-Bousiffi, W. El-Moudir, (2007), Libyan Petroleum Institute Experience in Evaluation of Desalination Plants in the Libyan Oil Sector, Desalination 206.

- International Atomic Energy Agency, (Dec. 2000), Examining the economics of Seawater Desalination Using the DEEP code, IAEA-TECDOC-1186.

- S Al-Hengari, W. ElMoudir, M. El-Bousiffi, (2015), Economic assessment of thermal desalination processes, Desalination and Water Treatment. Volume 55, - Issue 9 - PP. 2423-2436.

- E. Wheida, R. Verhoeven, (2004), Desalination as a water supply technique in Libya, Desalination 165. 